\title{
Water Balance in a Tropical Eucalyptus plantations in the Doce River Basin, Eastern Brazil
}

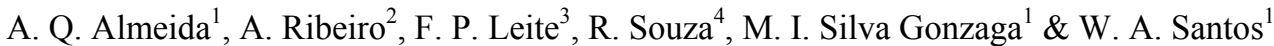 \\ ${ }^{1}$ Programa de Pós-graduação em Recursos Hídricos, Universidade Federal de Sergipe, São Cristóvão, Brazil \\ ${ }^{2}$ Departamento de Engenharia Agrícola, Universidade Federal de Viçosa, Minas Gerais, Brazil \\ ${ }^{3}$ Departamento de Pesquisa, CENIBRA, Belo Oriente, Minas Gerais, Brazil \\ ${ }^{4}$ Departamento de Energia Nuclaer, Universidade Federal de Pernambuco, Recife, Brazil \\ Correspondence: A. Q. Almeida, Programa de Pós-graduação em Recursos Hídricos, Universidade Federal de \\ Sergipe, Cidade Universitária Prof. José Aloísio de Campos, Av. Marechal Rondon, s/n, CEP: 49100-000, São \\ Cristóvão, SE, Brazil. Tel: 55-793-194-6423. E-mail: andre.almeida@ufs.br
}

Received: January 20, 2019

Accepted: March 3, 2019 Online Published: May 15, 2019

doi:10.5539/jas.v11n6p209

URL: https://doi.org/10.5539/jas.v11n6p209

\begin{abstract}
The rapid expansion of Eucalyptus plantations in Doce river basin, eastern Brazil, by changing the grassland and the natural surface cover in the savanna ecosystem, can potentially cause significant changes to water resources of the region. Especially for the higher amount of water transpired by the trees. The objective of this work was to model the water balance in an area cultivated with clonal E. grandis $\times$ urophylla in the Doce river basin, state of Minas Gerais, Brazil. Between October 2007 and September 2010, the water balance model estimated the daily variation of available soil water as a function of the water loss via evapotranspiration. Components of the evapotranspiration process were estimated by modifying the stomatal resistance of the Penman-Monteith equation. Evapotranspiration (ET) and precipitation (P), during the three years, were 3,467 mm and 3,439 $\mathrm{mm}$, respectively. The evapotranspiration/precipitation ratio (ET/P) was of 1.01 . Precipitation input was approximately balanced by water losses to evapotranspiration, without significant changes to water stored in soil and groundwater.
\end{abstract}

Keywords: Eucalyptus plantations, water balance, forestry, rutter model, interception

\section{Introduction}

Eucalyptus is the most widely planted hardwood genus in the world, covering more than 19 million hectares (Albaugh, Dye, \& King, 2013). Approximately 5.7 million hectares of the Brazilian territory in 2016 is cover with species of the genus Eucalyptus (IBÁ, 2017). Minas Gerais state alone accounts close $24 \%$ of the total planted area in Brazil, most planted in Doce river basin. In addition to existing plantations, the increase in the area planted with Eucalyptus forests in the Doce river basin is expected for the coming years, especially in areas currently destined for pasture land.

However, any change in land use and land cover promotes changes in the energy and water cycles of a basin, especially in the evapotranspiration and flow components of the watercourses (Zhou et al., 2015, Almeida et al., 2016). As fast-growing species exhibit a high water consumption through the transpiration process, the increase in planted area is expected to cause a significant increase in total evapotranspiration in the basin (Maier et al., 2004, 2017), which can compromise the water resources.

The many countries around the world there is much concern about their water consumption of Eucalyptus plantations, since forests play an important role in the capture and distribution of rainwater in the watersheds (Huang \& Zhao, 2014; Jones et al., 2017). In areas cultivated with Eucalyptus plantations, we expect to see higher evapotranspiration rates, resulting in decreased runoff and therefore the supply of water input to aquatic ecosystems (Reichert et al., 2017). Studies have shown that reforestation of degraded areas with Eucalyptus will often increase water loss by evapotranspiration, reducing water flow in streams and rivers (Reichert et al., 2017).

Modeling studies that assess components of the water balance in field cultivated with planted forests (mainly eucalyptus) are being conducted in various parts of the world, including South America (Smethurst, Almeida, \& 
Loos, 2015; Jones et al., 2017) and Australia (White et al., 2014), and show that there is a balance between the major inputs and outputs of water to and from the system, without significant changes in storage. In Brazil, several modeling studies have been performed on the water balance in watersheds planted with species of the genus Eucalyptus (Christina et al., 2017; Targa, Batista, Almeida, Pohl, \& Paula, 2017). However, few published studies conducted in the Doce River basin. It is not known the potential impacts of land use change on the water balance components.

The aim of the present study was, therefore, to model the water balance in an area cultivated with clonal Eucalyptus grandis $\times$ urophylla hybrids in the Doce river basin, the eastern portion of Brazil.

\section{Method}

\subsection{Study Area}

The study was performed in a 12-hectare area located in the Doce river Basin, eastern Minas Gerais, Brazil, in the municipality of Belo Oriente (Figure 1). The watershed of the Doce River is located in the southeastern portion of Brazil, with a total drainage area of $83,400.00 \mathrm{~km}^{2}$, with well over half $(82 \%)$ belonging to the state of Minas Gerais (Louzada et al., 2018). The air temperature range between 20 and $26^{\circ} \mathrm{C}$ (Cupolillo et al., 2008).

The topography the study area (12-hectare of Belo Oriente) is hilly, with elevation ranging between 250 and 310 meters, and an average slope of $25 \%$ (Almeida, 2012). The total area is covered with commercial plantations of the E. grandis $\times$ urophylla hybrid. Trees of the same clone were planted in May 2003, with a spacing of $3 \times 3$ meters, resulting in a stem density of about 1000 trees ha $^{-1}$. In this area, conventional forest management and soil conservation practices were performed, including planting along contour lines and other.

The regional climate, according to the Köppen classification, is hot and dry (Aw), with rainfall concentrated from October to March (Almeida, 2012). Average annual rainfall is $1,163 \mathrm{~mm}$, and the average annual air temperature is $25.2^{\circ} \mathrm{C}$. The soil characteristic of the watershed is typical Dystrophic Haplic, with clayey texture (Table 1).

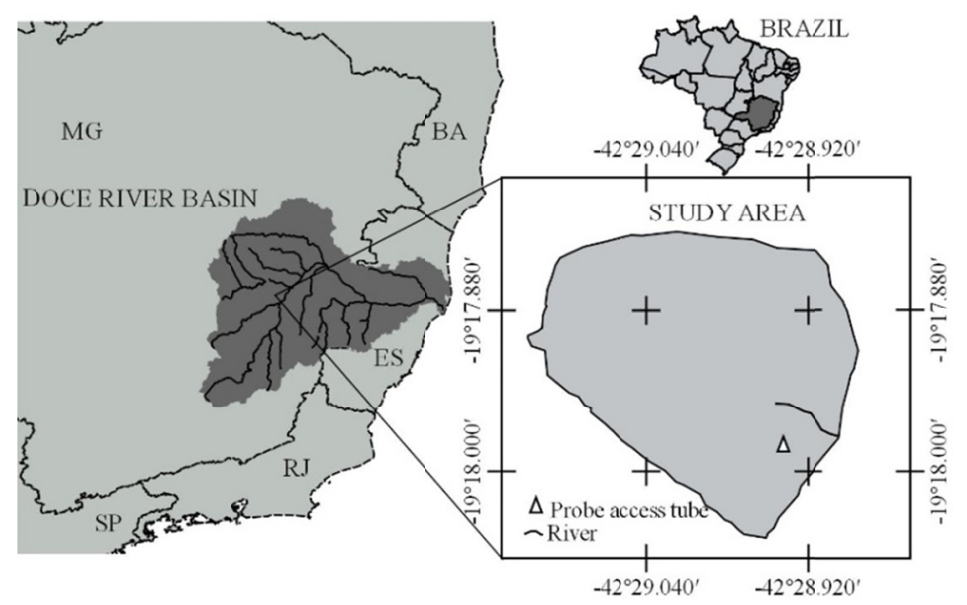

Figure 1. Location of the study area

\subsection{Water Balance}

The modeling of the water balance was performed for three years, between October 2007 and September 2010. The water balance model was based on some assumptions, considering input and output fluxes, a flux mass process. Modeling was performed using a daily step, considering the precipitation as the only water input to the system, and evapotranspiration, as the major output, considered in this study as the sum between transpiration, soil evaporation and interception of rainfall:

$$
\mathrm{ASW}_{\mathrm{i}}=\mathrm{ASW}_{\mathrm{i}+1}+\mathrm{P}_{\mathrm{i}}+\mathrm{I}_{\mathrm{i}}-\mathrm{T}_{\mathrm{i}}-\mathrm{E}_{\mathrm{si}}
$$

where, $\mathrm{ASW}_{\mathrm{i}}$, is the available soil water on day $i$; $\mathrm{ASW}_{\mathrm{i}-1}$, is the water available in the soil the day before; $\mathrm{P}_{\mathrm{i}}$, is the precipitation above the plant canopy on day $i ; \mathrm{I}_{\mathrm{i}}$, is the interception of rainfall by leaves and branches; $\mathrm{T}_{\mathrm{i}}$, is the plant transpiration on; and $\mathrm{E}_{\mathrm{si}}$, is the soil evaporation. All components were estimated and measured in water depth as mm. 
Processes such as capillary rise, deep drainage, surface runoff, and base flow were not considered in the model, as studies have shown negligible values in areas cultivated with eucalyptus plantations in Brazil (Soares \& Almeida, 2001). In this study, total evapotranspiration (ET) values were obtained by the sum of the plant transpiration (T), soil evaporation $\mathrm{E}(\mathrm{s})$ and canopy interception (I).

The interception of rainfall was estimated with the rutter model (Rutter, Morton, \& Robins, 1975). In this model, the evaporation rate of a saturated canopy is calculated by the Penman-Monteith equation (Monteith, 1965) assuming zero resistance of the canopy. The main input parameters of the Rutter model are shown in Table 1 . Values are based on the work of Steidle Neto et al. (2012) in commercial plantations of E. grandis $\times$ urophylla located in the same study area (Table 1). The estimation of transpiration (T) was based on the modified equation of Penman-Monteith for stomatal resistance, according to the methodology proposed by Carneiro et al. (2008):

$$
\lambda \mathrm{T}=\left[\mathrm{s}\left(\mathrm{R}_{\mathrm{n}}\right)+\left(3600 \rho_{\mathrm{a}} \mathrm{c}_{\mathrm{p}} \mathrm{VPD} / \mathrm{r}_{\mathrm{a}}\right)\right] /\left[\mathrm{s}+\gamma\left(1+\mathrm{r}_{\mathrm{s}} / \mathrm{r}_{\mathrm{a}}\right)\right]
$$

where $\lambda$ is the latent heat of vaporization ( $\left.\mathrm{MJ} \mathrm{kg}^{-1}\right), \mathrm{T}$ is the plant transpiration $\left(\mathrm{mm} \mathrm{h}^{-1}\right), \mathrm{s}$ is the slope of the saturation vapor pressure curve $\left(\mathrm{kPa}^{\circ} \mathrm{C}^{-1}\right)$ at mean air temperature, $\mathrm{R}_{\mathrm{n}}$ is the average daylight canopy net radiation $\left(\mathrm{MJ} \mathrm{m}^{-2} \mathrm{~h}^{-1}\right), \rho_{\mathrm{a}}$ is the density of air $\left(\mathrm{kg} \mathrm{m}^{-3}\right), \mathrm{c}_{\mathrm{p}}$ is the air specific heat $\left(\mathrm{MJ} \mathrm{kg}^{-1}{ }^{\circ} \mathrm{C}^{-1}\right)$, VPD is the vapor pressure deficit of the air $(\mathrm{kPa}), \gamma$ is the psychometric constant $\left(\mathrm{kPa}^{\circ} \mathrm{C}^{-1}\right), \mathrm{r}_{\mathrm{a}}$ is the canopy aerodynamic resistance $\left(\mathrm{s} \mathrm{m}^{-1}\right)$, and $\mathrm{r}_{\mathrm{s}}$ is the stomatal resistance $\left(\mathrm{s} \mathrm{m}^{-1}\right)$.

Canopy resistance was estimated by dividing the stomatal resistance by the leaf area index (LAI) of the plantation. The stomatal resistance was estimated with the model developed by Carneiro et al. (2008) for commercial eucalyptus plantations of the same species in eastern Brazil. In this model, $r_{s}$ is estimated as a function of the average air temperature $\left(\mathrm{t}_{\mathrm{med}},{ }^{\circ} \mathrm{C}\right), \mathrm{VPD}$, and the global solar irradiance $\left(\mathrm{R}_{\mathrm{g}}, \mathrm{W} \mathrm{m}^{-2} \mathrm{~s}^{-1}\right)$ on an hourly basis:

$$
\mathrm{r}_{\mathrm{s}}=418.74\left(\mathrm{VPD}_{\mathrm{med}} \mathrm{R}_{\mathrm{g}}^{-1}\right)^{0.5415}
$$

The LAI of the plantation was estimated non-destructively with a canopy analyzer LAI-2000 (Licor, Lincoln, Nebraska, USA). We measured LAI twice a year (in February and September) over the three years of the study. The value adopted for aerodynamic resistance was $83 \mathrm{~s} \mathrm{~m}^{-1}$, based on the study of Hatton, Walker, Dawes, \& Dunin (1992) in trees of e. maculate (Table 1).

Evaporation of the soil was estimated by the Penman-Monteith equation with soil resistance $\left(r_{\text {soil }}\right)$ decreasing rapidly as the available soil water decreases, as observed by Choudhury and Monteith (1988). The aerodynamic resistance of the soil $\left(\mathrm{R}_{\text {asoil }}\right)$ used was $0.012 \mathrm{~m} \mathrm{~s}^{-1}$, following Choudhury and Monteith (1988). The net radiation flux that reached the soil surface $\left(\mathrm{R}_{\mathrm{nsoi}}\right)$ was estimated based on the Beer law formulation.

The main meteorological input variables of the water balance model were temperature $\left({ }^{\circ} \mathrm{C}\right)$, relative humidity $(\%)$, solar radiation $\left(\mathrm{MJ} \mathrm{m}^{-2} \mathrm{~s}^{-1}\right)$, wind speed $\left(\mathrm{m} \mathrm{s}^{-1}\right)$, and rainfall $(\mathrm{mm})$. Data were obtained by sensors, collected in a 20-minute interval, of an automatic weather station (Vaisala ${ }^{\circledR}$ HMP45AC, Wind Speed and Direction Sensor, CS300 pyranometer, Tipping Bucket Raingauge) installed on top of a $30 \mathrm{~m}$ tower located about $5 \mathrm{~km}$ from the study site.

The available soil water was measured in the field using the neutron attenuation method. Neutron count readings were performed using a probe access tube (Model 503 DR-HIDROPROBE, CPN International Inc., Martinez California USA) measuring two feet in length and $45 \mathrm{~mm}$ in internal diameter, located in the center of the watershed. Measurements were performed on 20 times along the hydrological year at $0.2-\mathrm{m}$ soil intervals (layers) to a maximum depth of $2 \mathrm{~m}$. The total available soil water in the rooting zone for the measured data was calculated by summing the water content of all layers.

We adjusted site-specific calibration equations between neutron probe counts and soil moisture $\left(\mathrm{cm}^{3} \mathrm{~cm}^{-3}\right)$. Measurements of gravimetric moisture and neutron counting were performed at every $0.2 \mathrm{~m}$ depth of the soil profile to a depth of $2 \mathrm{~m}$. In these campaigns, three conditions of soil moisture content were simulated: dry $(20 \%)$, intermediate $(50 \%)$ and wet $(80 \%)$. For each depth, three replicates were performed with both the gravimetric method and the neutron probe. The calibration equations were adjusted based on the mean values for each depth of the soil profile.

The field-measured available soil water was compared against estimates provided by the water balance model. Validation was performed using the coefficient of determination $\left(\mathrm{R}^{2}\right)$, and root mean square error (RMSE). 
Table 1. Parameters values used in the study. The parameters in italic (13-19) were taken from the literature, as described in the text

\begin{tabular}{|c|c|c|}
\hline Parameters & Number & Value \\
\hline Sand: $0-2 \mathrm{~m}(\%)$ & 1 & 32 \\
\hline Silt: $0-2 \mathrm{~m}(\%)$ & 2 & 12 \\
\hline Clay: $0-2 \mathrm{~m}(\%)$ & 3 & 56 \\
\hline Soil density $\left(\mathrm{g} \mathrm{cm}^{-3}\right)$ & 4 & 1.1 \\
\hline Porosity $(\%)$ & 5 & 53 \\
\hline Depth of the root system (m) & 6 & 2.0 \\
\hline Field capacity (mm) & 7 & 654.5 \\
\hline Permanent wilting point $(\mathrm{mm})$ & 8 & 451 \\
\hline Available water capacity in the soil (mm) & 9 & 203.5 \\
\hline Initial water available in the soil (mm) & 10 & 10 \\
\hline Beer-Lambert (k) & 11 & -0.42 \\
\hline $\operatorname{LAI}\left(\mathrm{m}^{2} \mathrm{~m}^{-2}\right)$ & 12 & 1.8 \\
\hline Aerodynamic resistance: $r_{a}\left(m s^{-1}\right)$ & 13 & 83 \\
\hline Maximum soil resistance: $r_{\text {solo }}\left(\mathrm{m} \mathrm{s}^{-1}\right)$ & 14 & 0.0025 \\
\hline Aerodynamic resistance of the soil: $r_{\text {asolo }}\left(\mathrm{m} \mathrm{s}^{-1}\right)$ & 15 & 0.012 \\
\hline Free throughfall coefficient: $p(a d m)$ & 16 & 0.42 \\
\hline Stemflow partitioning coefficient: pt (adm) & 17 & 0.03 \\
\hline Canopy storage capacity: $S(\mathrm{~mm})$ & 18 & 0.24 \\
\hline Trunk storage capacity: St (mm) & 19 & 0.04 \\
\hline
\end{tabular}

\section{Results}

The seasonal behavior of the meteorological variables was similar for the three years, with the highest values coinciding with the months of the rainy season (Figure 2). Total rainfall during the study period was approximately $3439 \mathrm{~mm}$. The first and second experiment years presented the lowest $(785 \mathrm{~mm})$ and highest $(1517 \mathrm{~mm})$ total precipitation values, respectively. December 2009 was the month with the highest precipitation (328 $\mathrm{mm}$ ), accounting for about $21 \%$ of the annual precipitation. Precipitation in third was $1136 \mathrm{~mm}$, which is close to the historical average (1991-2012) of $1163 \mathrm{~mm}$.

The average annual air temperature (Figure 2a) during the three years of analysis was approximately $23{ }^{\circ} \mathrm{C}$. June and July presented the lowest monthly air temperatures. The highest temperatures were concentrated from December to March, where the highest value was observed for February $2010\left(27^{\circ} \mathrm{C}\right)$. The average global solar irradiance was $18 \mathrm{MJ} \mathrm{m}^{-2} \mathrm{~h}^{-1}$ (Figure 2b). Energy availability was always higher during the wet period of the hydrological years, from October to March. The annual average vapor pressure deficit (VDP) was approximately $0.8 \mathrm{kPa}$. The highest VPD value was recorded for October 2007 (1.62 kPa).

Transpiration was the major avenue of water loss in the plantation in all months, with an average of 77, 75 and $88 \mathrm{~mm} \mathrm{month}^{-1}$ for years 1, 2, and 3, respectively (Figure 3). In the second hydrologic year, (Oct/2008-Sep/2009), the monthly behavior of transpiration differed from the other years, with a decrease in the second month and subsequent increase in the following months. From December to April, the monthly transpiration was constant and close to $90 \mathrm{~mm}$, a consequence of the high precipitation values during this period (Figure $3 \mathrm{~b}$ ). Another interesting fact observed is the strong correlation between monthly rainfall and the amount of water that is intercepted by the canopy. 


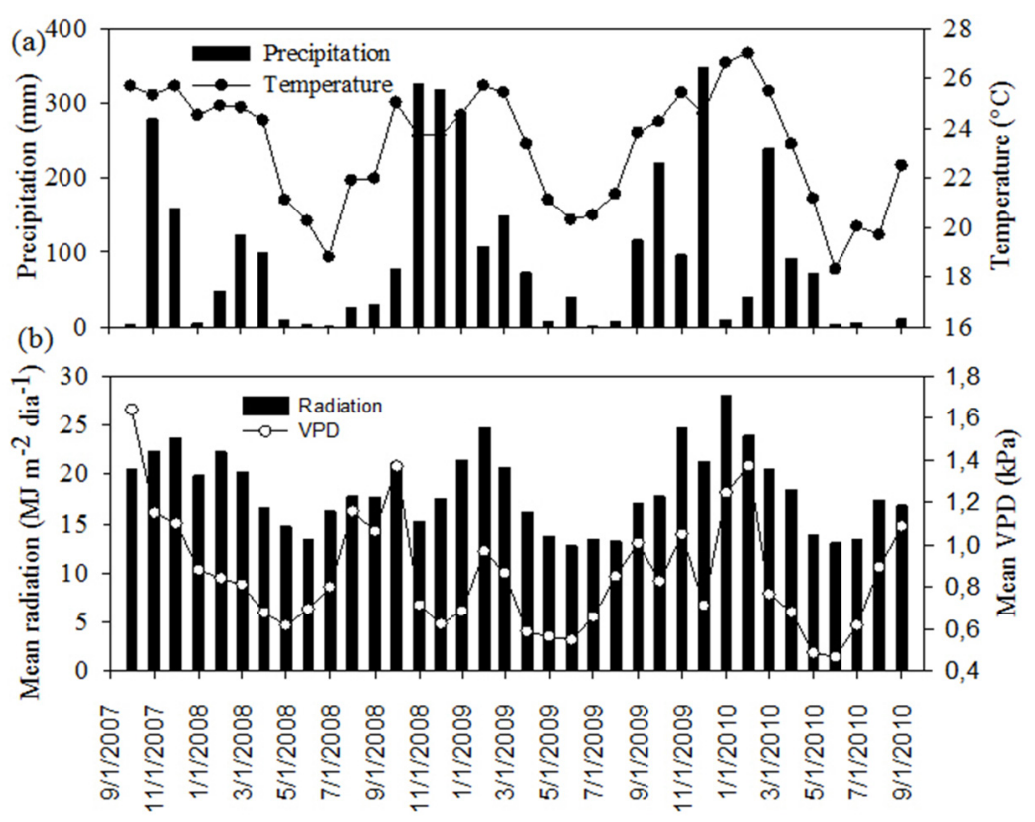

Figure 2. Total monthly rainfall, average monthly air temperature, global solar radiation, and VDP observed for the study area during the three years analyzed in this study
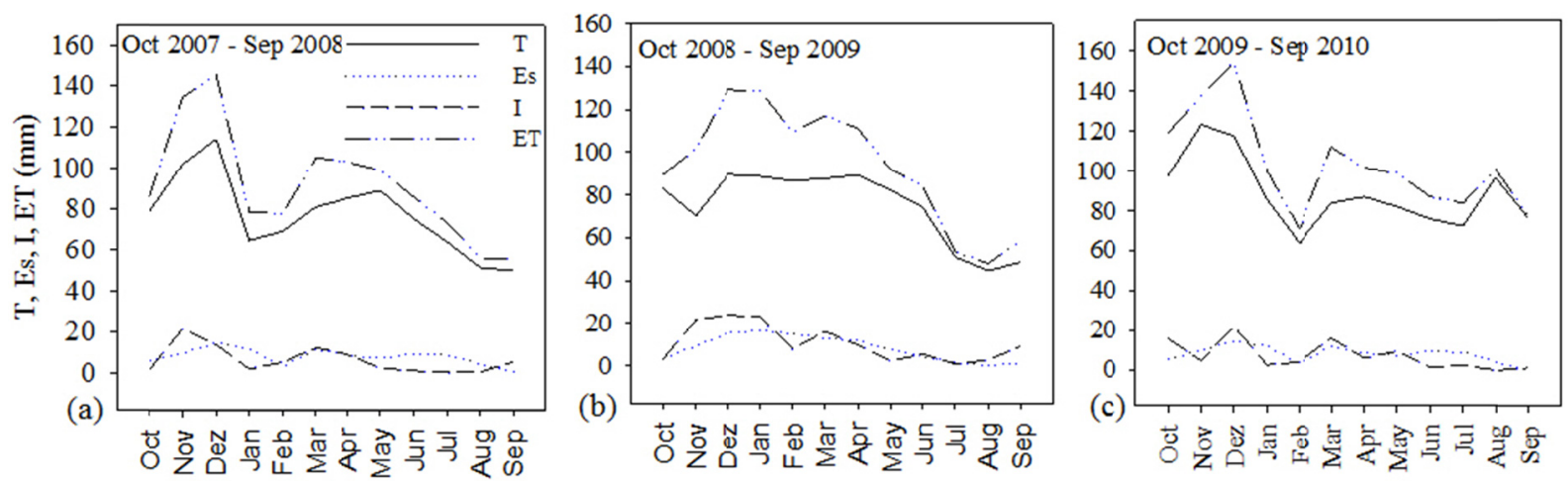

Figure 3. Monthly water balance for (a) year 1 (October 2007-September 2008), (b) year 2 (October 2008-September 2009), and (c) year 3 (October 2009-September 2010). P, precipitation; T, plant transpiration; Es, oil evaporation; I, canopy interception; and $\mathrm{ET}\left(\mathrm{T}+\mathrm{E}_{\mathrm{s}}+\mathrm{I}\right)$, evapotranspiration, al in $\mathrm{mm}$

During the rainy season (October to March), the interception was greater than soil evaporation (Table 2). This changed in the dry season, which was characterized by higher soil evaporation and a lower interception. The lowest precipitation $(785 \mathrm{~mm})$, observed in the first year (Oct/2007-Sep/2008), was far below the historical average for the region of $1163 \mathrm{~mm}$.

The measured and modeled values of water content in the soil are shown in Figure 4. There was a close relationship between the values estimated by the model and those measured in the field. After a long time without precipitation events, soil water content values (ASW) tend to decrease. After the first precipitation events occur, the ASW values increase again ( $200 \mathrm{~mm})$. 
Table 2. Annual and seasonal (wet vs. dry) water balance

\begin{tabular}{llllllll}
\hline Período & $\mathrm{P}$ & $\mathrm{T}$ & $\mathrm{E}_{\mathrm{s}}$ & $\mathrm{I}$ & $\mathrm{ET}$ & $\Delta \mathrm{ASW}$ & $\mathrm{ET} \mathrm{P}^{-1}$ \\
\hline Oct 2007-Sept 2008 (year) & 785 & 927 & 96 & 76 & 1103 & -318 & 1.41 \\
Oct 2007-Mar 2008 (wet) & 617 & 511 & 57 & 58 & 629 & -12 & 1.02 \\
Apr 2008-Sept 2008 (dry) & 168 & 416 & 39 & 19 & 474 & -306 & 2.83 \\
Oct 2008-Sept2009 (year) & 1517 & 898 & 100 & 128 & 1126 & 390 & 0.74 \\
Oct 2008-Mar 2009 (wet) & 1273 & 508 & 73 & 97 & 678 & 594 & 0.53 \\
Apr 2009-Sept2009 (dry) & 244 & 390 & 26 & 30 & 448 & -203 & 1.83 \\
Oct 2009-Sept 2010 (year) & 1136 & 1059 & 96 & 79 & 1235 & -98 & 1.09 \\
Oct 2009-Mar 2010 (wet) & 953 & 569 & 57 & 64 & 691 & 262 & 0.73 \\
Apr 2010-Sept 2010 (dry) & 183 & 490 & 39 & 20 & 549 & -366 & 3.00 \\
Total & 3439 & 2885 & 292 & 289 & 3467 & -28 & 1.01 \\
\hline
\end{tabular}

Note. P, precipitation; T, plant transpiration; Es, soil evaporation; I, canopy interception; ET, evapotranspiration $\left(\mathrm{T}+\mathrm{E}_{\mathrm{s}}+\mathrm{I}\right)$; and $\Delta \mathrm{ASW}$, the variation in available soil water.

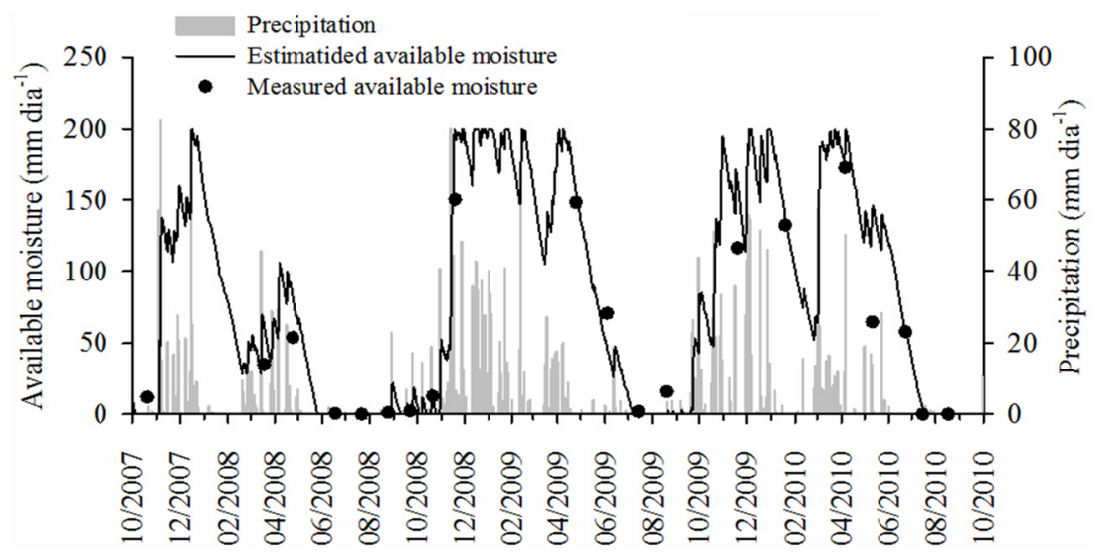

Figure 4. Modeled (line) and measured (circle) values of available soil water to the depth of the rooting zone (2 $\mathrm{m}$ ), with rainfall values (bars) for the three hydrological years

\section{Discussion}

The results showed above provide information on the main components of the water balance in an area planted with fast-growing plantations of $E$. grandis $\times$ urophylla hybrid. The low rainfall observed in the first year (Oct/2007-Sep/2008), among other factors (Gharun et al., 2014), contributed to the lowest observed values of evapotranspiration, with a cumulative total of $1104 \mathrm{~mm} \mathrm{yr}^{-1}$. Low availability of soil water induces stomatal closure (Carneiro et al., 2008), thereby reducing the processes of gas exchange between the plant and the environment, mainly the transpiration (Ouyang et al., 2017), specially when the soil moisture is below the wilting point (Souza et al., 2016). In the first year analyzed in this work, we observed the occurrence of a high water deficit in the soil $(-318 \mathrm{~mm})$. However, in the other hydrological years, with annual totals greater than (1517) and similar to (1136) the annual historical average for the region, we observed an excess of soil water, suggesting a balance between the main inputs and outputs.

Another water balance component which was reduced due to the low precipitation values was the interception by tree leaves, branches, and trunks. Although small, the average interception by vegetation throughout the year was close to $10 \%$. Interception, therefore, played an important role in the water balance of the area, affecting evapotranspiration even in the low incidence of rainfall. The process of rainfall interception was responsible for the consumption of $9 \%$ of the total rainfall during the hydrological year. A similar proportion of water intercepted in eucalyptus planting was found by Trevisan et al. (2012).

Although estimated via the Rutter model, the percentage intercepted by the forest canopy in the watershed was similar to that measured in the field in eucalyptus plantations in eastern Brazil (Steidle Neto et al., 2012). The total intercepted by vegetation cover is highly correlated with the intensity and duration of rainfall, canopy 
architecture, LAI, morphological characteristics of the trunk and the number of trees per hectare, and may contribute with up to $24 \%$ of incident rainfall (Reichert et al., 2017).

The evaporation of water from the soil to the atmosphere redistributed about $12 \%$ of the water input, also playing an important role in the evapotranspiration process. This value was similar to that found by Soares and Almeida (2001) in an experimental watershed with a nine-year-old plantation of Eucalyptus grandis, located in the state of Espírito Santo, Brazil. The low rainfall caused a negative balance $(-12 \mathrm{~mm})$ of available water in the soil, even in the rainy season of the hydrological year. Under these conditions, the water demand of forest species can be met by the capillary rise, reversing the direction of the flow of groundwater, and removing water from the deeper layers of the soil (Soares \& Almeida, 2001). Also, as a consequence of the low precipitation values, the ratio of evapotranspiration to precipitation $\left(\mathrm{ET} \mathrm{P}^{-1}\right)$ was always greater than one during the year, even in the wet season (1.02). This indicates that there was no equilibrium between the input and output of water in the system, which differs from results by Almeida and Soares (2003).

The second year showed the highest precipitation $(1517 \mathrm{~mm})$, with events well distributed among months and periods considered. The total precipitation in the rainy season alone (Oct/2008-Mar/2009) was higher than the total rainfall observed in the other two hydrological years (Oct/2007 to Sep/2008 and Oct/2009-Sep/2010), resulting in accumulation of water stored in soil and groundwater. In the second hydrologic year analyzed (Oct/2008-Sep/2009), the average daily evapotranspiration was $3.08 \mathrm{~mm} \mathrm{day}^{-1}$, corresponding to $74 \%$ of the rainfall in that year. The total transpired in the year by the plantation corresponded to $59 \%$ of the rainfall. During the wet season, this number reduced to $40 \%$. The canopy and trunk of the trees intercepted only $8 \%$ of the annual rainfall. Soil evaporation was responsible for the consumption of only $6.5 \%$ of the rainfall. The variation in water storage in the soil was always positive, regardless of the period of the year, resulting in ET $\mathrm{P}^{-1}$ ratios of less than one.

With total precipitation near the historical average of $1163 \mathrm{~mm}$, the average daily evapotranspiration in the third year was $3.38 \mathrm{~mm}$ day $^{-1}$. Transpiration was responsible for the consumption of $93 \%$ of the rainfall. When considering the entire year (Oct/2009-Sep/2010), an equilibrium is observed between inputs and outputs of water This suggests that in years with rainfall close to the historical average, evapotranspiration consumes nearly $100 \%$ of the incident water in this site.

When considering the entire period, of the total rainfall $(3439 \mathrm{~mm})$, whereas $84 \%$ left the system via transpiration, $9 \%$ via soil evaporation and $8 \%$ was intercepted by leaves and trunks (Table 2 ). In this same period, the ET $\mathrm{P}^{-1}$ ratio was approximately one, indicating that there is a balance between the components of the water balance in this site. Evaluating the water consumption by commercial eucalyptus plantations on the east coast of Brazil, Almeida and Soares (2003) found ET $\mathrm{P}^{-1}$ ratios close to one, even when the hydrological year presented total precipitation greater than the historical average of the region.

The model accurately estimated values of available soil water $\left(\mathrm{R}^{2}=0.9\right.$, $\mathrm{RMSE}=5.8 \mathrm{~mm}$ or $\left.11 \%\right)$, with performance similar to that observed in the work of Almeida, Ribeiro, and Leite (2013), and in Reis et al. (2014), in which growth and water balance were modeled in plantations of $E$. grandis located on the east coast of Brazil. The good performance of the water balance model indicates that the estimated values of evapotranspiration were not overestimated. The available soil water came close to the permanent wilting point $(451 \mathrm{~mm})$ only in months with a low occurrence of rainfall (June to September).

\section{Conclusions}

1). In the hydrological years with precipitation lower than average and during the dry seasons the ratio of ET/P was greater than 1 .

2). A detailed analysis of the components of the water balance shows that the natural water availability in the soil was not compromised during the hydrological years analyzed, guaranteeing water storage in the soil.

3). The simple model was able to estimate the water balance components satisfactorily in the area with eucalyptus which ensures its application in future studies.

\section{References}

Albaugh, J. M., Dye, P. J., \& King J. S. (2013). Eucalyptus and Water Use in South Africa. International Journal of Forestry Research, 01-11. https://doi.org/10.1155/2013/852540

Almeida, A. C., \& Soares, J. V. (2003). Comparação entre uso de água em plantações de Eucalyptus grandis e Floresta Ombrófila densa (Mata Atlântica) na costa leste do Brasil. Revista Árvore, 27, 159-170. https://doi.org/10.1590/S0100-67622003000200006 
Almeida, A. Q., Ribeiro, A., \& Leite, F. P. (2013). Modelagem do balanço hídrico em microbacia cultivada com plantio comercial de Eucalyptus grandis $\times$ urophylla no leste de Minas Gerais, Brasil. Revista Árvore, 37, 547-556. https://doi.org/10.1590/S0100-67622013000300018

Almeida, A.Q. (2012). Dinâmica hídrica em microbacias cultivadas com eucalipto e pastagem no leste de Minas Gerais (Doctoral dissertation, Universidade Federal de Viçosa, Minas Gerais).

Almeida, A. C., Smethurst, P. J., Siggins, A., Cavalcante, R. B. L., \& Borges, N. (2016). Quantifying the effects of Eucalyptus plantations and management on water resources at plot and catchment scales. Hydrological Processes, 30, 4687-4703. https://doi.org/10.1002/hyp.10992

Carneiro, R. L., Ribeiro, A., Huaman, C. A. M., Lite, F. P., Sediyama, G. C., \& Neves, J. C. L. (2008). Consumo de água em plantios de eucalipto: Parte 2 modelagem da resistência estomática e estimativa da transpiração em tratamentos irrigados e não-irrigados. Revista Árvore, 32, 11-18. https://doi.org/10.1590/S0100-67622 008000100001

Christina, M., Nouvellon, Y., Laclau, J.-P., Stape, J. L., Bouillet, J.-P., Lambais, G. R., \& Le Maire, G. (2017). Importance of deep water uptake in tropical eucalypt forest. Functional Ecology, 31, 509-519. https://doi.org/10.1111/1365-2435.12727

Choudhury, B. J., \& Monteith, J. L. (1988). A four-layer model for the heat budget of homogeneous land surfaces. Quarterly Journal of the Royal Meteorological Society, 114, 373-398. https://doi.org/10.1002/qj. 49711448006

Cupolillo, F., Abreu, M. L., Vianello, R. L. (2008). Climatologia da bacia do Rio Doce e sua relação com a topografia local. GEOgrafias, 4(1), 45-60.

Gharun, M., Vervoort, R. W., Turnbull, T. L., \& Adams, M. A. (2014). A test of how coupling of vegetation to the atmosphere and climate spatial variation affects water yield modelling in mountainous catchments. Journal of Hydrology, 514, 202-213. https://doi.org/10.1016/j.jhydrol.2014.04.037

Hatton, T. J., Walker, J., Dawes, W. R., \& Dunin, F. X. (1992). Simulation of hydroecological responses to elevated $\mathrm{CO}_{2}$ at the catchment scale. Australian Journal Botany, 40, 679-696. https://doi.org/10.1071/ BT9920679

Huang, G. Q., \& Zhao, Q. G. (2014). The history, status quo, ecological problems and countermeasures of Eucalyptus plantations in Guangxi. Acta Ecologica Sinica, 34(18), 5142-5152.

IBÁ (Indústria Brasileira de Árvores). (2017). Relatório anual IBÁ 2017. Retreived from http://iba.org/pt/ biblioteca-iba/publicacoes

Jones, J., Almeida, A., Cisneros, F., Iroumé, A., Jobbágy, E., Lara, A., ... Villegas, J. C. (2016). Forest and Water in South America. Hydrological Processes, 31, 1-9. https://doi.org/10.1002/hyp.11035

Louzada, F. L. R. O., Xavier, A. C., \& Pezzopane, J. E. M. (2018). Climatological Water Balance with data Estimated by Tropical Rainfall Measuring Mission for the Doce River Basin. Engenharia Agrícola, 38(3), 376-386. https://doi.org/10.1590/1809-4430-eng.agric.v38n3p376-386/2018

Maier, C. A., Albaugh, T. J., Cook, R. I., Hall, K., McInnis, D., Johnsen, K. H., ... Vose, J. M. (2017). Comparative water-use in short rotation Eucalyptus benthamii and Pinus taeda trees in the Southern United States. Forest Ecology and Management, 397, 126-138. https://doi.org/10.1016/j.foreco.2017.04.038

Monteith, J. L. (1965). Evaporation and environment. Proceedings of the 19th Symposium of the Society for Experimental Biology (pp. 205-234).

Reichert, J. M., Rodrigues, M. F., Peláez, J. J. Z., Lanza, R., Minella, J. P. G., Arnold, J. G., \& Cavalcante, R. B. L. (2017). Water balance in paired watersheds with eucalyptus and degraded grassland in Pampa biome. Agricultural and Forest Meteorology, 237, 282-295. https://doi.org/10.1016/j.agrformet.2017.02.014

Reis, M .G., Ribeiro, A., Baesso, R. C. E., Souza, W. G., Fonseca, S., \& Loos, R. A. (2014). Balanço hídrico e de energia para plantios de eucalipto com cobertura parcial do solo. Ciência Florestal, 24, 117-126. https://doi.org/10.5902/1980509813329

Rutter, A. J., Morton, A. J., \& Robins, P. C. (1975). A predictive model of rainfall interception in forests, II. Generalization of the model and comparison with observations in some coniferous and hardwood stands. Journal Applied Ecology, 12, 367-380. https://doi.org/10.2307/2401739 
Smethurst, P. J., Almeida, A. C., \& Loos, R. A. (2015). Stream flow unaffected by Eucalyptus plantation harvesting implicates water use by the native forest streamside reserve. Journal of Hydrology: Regional Studies, 3, 187-198. https://doi.org/10.1016/j.ejrh.2014.11.002

Soares, J. V., \& Almeida, A. C. (2001). Modeling the water balance and soil water fluxes in a fast growing Eucalyptus plantation in Brazil. Journal of Hydrology, 253, 130-147. https://doi.org/10.1016/S00221694(01)00477-2

Souza, R., Feng, X., Antonino, A., Montenegro, S., Souza, E., \& Porporato, A. (2016). Vegetation response to rainfall seasonality and interannual variability in tropical dry forests. Hydrological Processes, 30, 3583-3595. https://doi.org/10.1002/hyp.10953

Steidle N., A. J., Ribeiro, A., Lopes, D. C., Sacramento Neto, O. B., Souza, W. G., \& Santana, M. O. (2012). Simulation of Rainfall Interception of Canopy and Litter in Eucalyptus Plantation in Tropical Climate. Forest Science, 58, 54-60. https://doi.org/10.5849/forsci.09-120

Targa, M. S., Batista, G. T., Almeida, A. P. S., Pohl, E., \& Paula, G. R. (2017). Evaluation of soil water storage in native forest and eucalyptus areas. Revista Ambiente \& Água, 12, 973-984. https://doi.org/10.4136/ ambi-agua.2195

Trevisan, R., Salemi, L. F., Groppo, J. D., Silva, R. W. C., Martinelli, L. A., \& Moraes, J. M. (2012). Dinâmica da Água em uma Microbacia com Cobertura Florestal de Eucalipto Localizada na Serra do Mar no Vale do Paraíba do Sul. Revista Brasileira de Recursos Hídricos, 17, 207-216. https://doi.org/10.21168/rbrh.v17n4. p207-216

White, D. A., McGrath, J. F., Ryan, M. G., Battaglia, M., Mendham, D. S., Kina, J. \& Hunt, M. E. (2014). Managing for water - use efficient wood production in Eucalypts globulus plantations. Forest Ecology and Management, 331, 272-280. https://doi.org/10.1016/j.foreco.2014.08.020

Zhou, S., Huang, Y., Wei, Y., \& Wang, G. (2015). Socio-hydrological water balance for water allocation between human and environmental purposes in catchments. Hydrology and Earth System Sciences, 19, 3715-3726. https://doi.org/10.5194/hess-19-3715-2015

\section{Copyrights}

Copyright for this article is retained by the author(s), with first publication rights granted to the journal.

This is an open-access article distributed under the terms and conditions of the Creative Commons Attribution license (http://creativecommons.org/licenses/by/4.0/). 